\title{
HUBUNGAN PENGETAHUAN REMAJA PUTRI TENTANG KEPUTIHAN DENGAN PERILAKU HYGIENITAS GENETALIA
}

\section{THE RELATION OF ADOLESENT GIRL KNOWLEDGE ABOUT FLUOR ALBUS WITH GENITAL HYGINE BEHAVIOR}

\author{
Luluk Susiloningtyas $1 *$ \\ ${ }^{l}$ STIKes Pamenang \\ *Korespondensi Penulis : luluksusiloningtyas@gmail.com
}

\begin{abstract}
Abstrak
Di Indonesia, wanita yang mengalami keputihan sebanyak 75\%, sebagian besar 50\% terjadi pada remaja, $25 \%$ pada Wanita Usia Subur (WUS). Keputihan pada remaja biasanya terjadi sebelum dan sesudah menstruasi yang bersifat fisiologis. Bila perilaku perawatan hygienitas genetalia tidak baik, bisa dimungkinkan menjadi penyebab keputihan patologis yang menimbulkan rasa tidak nyaman dan jangka waktu lama bisa menyebabkan infeksi pada panggul dan infertilitas. Salah satu faktor penghambat berperilaku sehat adalah kurangnya pengetahuan dan kesadaran individu tentang hygienitas genetalia termasuk pencegahan dan penanganan keputihan. Tujuan penelitian adalah mengetahui hubungan pengetahuan remaja putri tentang keputihan dengan perilaku hygienitas genetalia di SMP Negeri 1 Pare Kediri.

Desain penelitian yang digunakan analitik korelasional dengan pendekatan cross sectional. Sampel penelitian adalah siswi yang sudah pernah menstruasi di SMPN 1 Pare berjumlah 38 siswi. Teknik sampling yang digunakan Simple Random Sampling. Instrumen penelitian pengetahuan remaja putri tentang keputihan dengan kuesioner dengan skala ordinal dan perilaku hygienitas genetalia menggunakan kuesioner dengan skala ordinal. Analisa data menggunakan Uji Spearman Rank.

Hasil penelitian dari 38 responden prosentase terbesar tingkat pengetahuan remaja putri tentang keputihan berada dalam kategori cukup, sebanyak 19 responden (50\%) dan perilaku hygienitas genetalianya sebagian besar dalam kategori baik 29 responden (76,3\%). Ada hubungan pengetahuan remaja putri tentang keputihan dengan perilaku hygienitas genetalia dengan hasil uji signifikasi diperoleh $\mathrm{p}$ value $=0,000$, dengan nilai koefisien korelasi $\left(r^{2}\right)=0,780$ dengan tingkat hubungan positif, artinya semakin baik pengetahuan maka semakin baik perilaku hygienitas genetalianya

Rekomendasi penelitian untuk remaja putri diharapkan menambah pengetahuan tentang kesehatan reproduksi terutama tentang hygienitas genetalia.
\end{abstract}

Kata Kunci: Pengetahuan, Perilaku Higienitas Genetalia, Remaja Putri

\begin{abstract}
In Indonesia, women who experience fluor albus much as 75\%, mostly 50\% occur in adolescents, $25 \%$ in women of childbearing age (WUS). Leucorrhoea in adolescents usually occurs before and after menstruation which is physiological. If the behavior of genetal hygienic treatment is not good, it may be possible to cause pathological vaginal discharge that causes discomfort and can cause long-term infection of the pelvis and infertility. One of the inhibiting factors for healthy behavior is the lack of knowledge and awareness of individuals about genetal hygienity, including the prevention and treatment of vaginal discharge. The purpose of this study was to determine the relationship of adolescent girls' knowledge of vaginal discharge with genetical hygienic behavior in SMP Negeri 1 Pare Kediri.The study design used correlational analytic with cross sectional approach. The research sample was 38 students who had menstruated at SMPN 1 Pare. The sampling technique used is Simple Random Sampling. The research instrument of young woman's knowledge about vaginal discharge with a questionnaire with an ordinal scale and genetal hygienic behavior using a questionnaire with an ordinal scale. Analysis of data using the Spearman Rank Test.The results of the 38 respondents were most of the knowledge of young women about fluor albusis sufficient 19 respondents $(50 \%)$ and most of the genetic hygienec behaviors
\end{abstract}


were 29 respondents (76,3\%). There is a relationship between adolescent girls' knowledge about fluor albus with genetal hygienic behavior with the significance test results obtained $p$ value $=$ 0,000 , with the Spearman correlation coefficient $(r)=0.780$ with a positive relationship level, meaning that the better the knowledge the better the geneticity hygienic behavior

Research recommendations for adolescent girls are expected to increase knowledge about reproductive health, especially about genetal hygienic.

Keyword: Knowledge, Hygiene Behavior Genetalia,Young Women

\section{Pendahuluan}

Ada sekitar 60.861 .350 remaja berusia 10-24, atau sekitar 30,2\% dari total penduduk di Indonesia. Sebagian besar remaja tidak memiliki pengetahuan yang akurat tentang kesehatan reproduksi dan seksualitas, mereka juga tidak memiliki akses terhadap pelayanan dan informasi kesehatan reproduksi. Informasi yang biasanya didapat dari teman atau media yang sering tidak akurat ${ }^{1}$. Kesehatan reproduksi dikalangan wanita temasuk remaja harus memperoleh perhatian yang serius, salah satunya adalah keputihan yaitu masalah yang berhubungan dengan organ seksual wanita. Keputihan biasanya disebabkan oleh jamur atau virus bakteri yang tentu saja masalah ini amat mengganggu, karena biasanya wanita akan mengeluarkan aroma yang tidak sedap dari organ intimnya selain juga merasa gatal yang sering mengganggu ${ }^{2}$.

Keluhan keputihan sering terjadi pada perempuan dan tidak mengenal usia. Keputihan ada yang secara normal (Fisiologis) maupun abnormal (Patologis). Pada masa remaja akan mengalami perkembangan pada organ reproduksinya. Organ reproduksi pada remaja perempuan lebih sensitif daripada laki-laki karena saluran reproduksimya lebih pendek sehingga diperlukan perhatian terutama yang belum berperilaku sehat untuk mencegah keputihan patologis. Begitu juga keputihan fisiologis (normal) yang terjadi pada remaja yang biasanya terjadi sebelum dan sesudah menstruasi. Bila perilaku perawatan hygienitas genetalia yang tidak baik, bisa dimungkinkan menjadi penyebab keputihan patologis. Keputihan patologis menimbulkan rasa tidak nyaman dan dalam jangka waktu lama akan menyebabkan beberapa penyakit serius diantaranya adalah infeksi pada panggul dan bisa mengakibatkan infertilitas atau kemandulan ${ }^{3,4}$.

Berdasarkan data statistik Indonesia dari 43,3 juta jiwa remaja berusia 15-24 tahun berperilaku tidak sehat seperti penggunaan pentyliner yang tidak seperlunya, pemakaian antiseptik, cara cebok yang salah. Ini merupakan salah satu penyebab dari keputihan. Di Indonesia, wanita yang mengalami keputihan sebanyak $75 \%$ yang sebagian besar $50 \%$ terjadi pada remaja dan $25 \%$ pada Wanita Usia Subur (WUS). Keputihan yang terjadi pada remaja biasanya terjadi sebelum dan sesudah menstruasi yang bersifat fisiologis. Bila perilaku perawatan hygienitas genetalia tidak baik, bisa dimungkinkan menjadi penyebab keputihan patologis yang menimbulkan rasa tidak nyaman dan jangka waktu lama bisa menyebabkan infeksi pada panggul dan infertilitas. Salah satu faktor penghambat berperilaku sehat adalah kurangnya pengetahuan dan kesadaran individu tentang hygienitas genetalia termasuk pencegahan dan penanganan keputihan ${ }^{5,6}$.

Ada beberapa faktor penghambat untuk berperilaku sehat dalam upaya pencegahan dan penanganan keputihan patologis di antaranya adalah kurangnya pengetahuan dan kesadaran individu atau remaja tentang hygienitas, pencegahan dan penanganan keputihan seperti cara membersihkan genitalia eksterna, pemakaian dan kebersihan celana dalam, penggunaan antiseptik dan obat cebok, pemakaian pembalut saat menstruasi, penggunaan pantyliner dan bedak, dan kebersihan kamar mandi. Oleh karena itu pendekatan pemberdayaan perempuan dan remaja putri harus dilaksanakan melalui pemberian informasi lengkap dan terkini untuk meningkatkan pengetahuan dan kesadaran remaja tentang resiko terjadinya keputihan patologis dan cara pencegahannya ${ }^{1}$.

Dari hasil studi pendahuluan yang dilakukan pada bulan Januari 2017 di SMP Negeri 1 Pare Kediri didapatkan dengan mewawancarai 10 remaja putri tentang keputihan, yang sudah mengalami keputihan yaitu 7 orang (70\%), sebanyak 3 orang (30\%) belum pernah mengalami keputihan. Setelah ditanyakan tentang hygienitas genetalia, maka diperoleh 6 orang $(60 \%)$ belum menjaga hygienitas genetalia dengan baik seperti 
membersihkan genetalia dengan sabun sirih, tidak menjaga genetalianya agar tetap kering dan menggunakan pentiliner tidak seperlunya, 4 orang (40\%) selalu menjaga hygienitas genetalia dengan baik, kebenaran dari mereka adalah frekuensi ganti celana dalam mereka yang bila terasa basah mereka langsung menggantinya dikarenakan mereka merasa risih, jadi paling tidak sehari mereka minimal dua kali ganti celana dalam. Hal tersebut terjadi disebabkan kurangnya informasi, baik dari sekolah, maupun lingkungan keluarga, dan kurangnya pengalaman dari remaja putri.

Untuk mengatasi masalah tersebut perlu dilakukan upaya peningkatan kesehatan reproduksi remaja. Petugas kesehatan dapat memberikan pelayanan, penyuluhan dan konseling mengenai kesehatan alat reproduksi semenjak dini untuk mencegah terjadinya keputihan dan menyelesaikan permasalahan hygienitas alat reproduksi sehingga dapat menjadi pemahaman, sikap dan perilaku terutama pada remaja. Berdasarkan uraian di atas, maka peneliti tertarik untuk melakukan penelitian dengan judul "Hubungan Pengetahuan Remaja Putri Tentang Keputihan dengan Perilaku Hygienitas Genetalia di SMP Negeri 1 Pare Kediri tahun 2018”.

\section{Metode Penelitian \\ Desain Penelitian}

Desain penelitian yang digunakan dalam penelitian ini adalah penelitian analitik korelasional dengan pendekatan cross sectional.

\section{Variabel Penelitian}

Variabel independen (bebas) adalah pengetahuan remaja putri tentang keputihan. Variabel terikat atau variabel dependent. Variabel dependent adalah perilaku hygienitas genetalia.

\section{Subyek Penelitian}

Jumlah populasi adalah semua siswi SMPN 1 Pare yang sudah mestruasi, teknik sampling menggunakan simple random sampling sehingga didapatkan sampel penelitian sebanyak 38 responden yang termasuk dalam kriteria inklusi meliputi umur responden 13-15 tahun, responden sudah mengalami menstruasi, responden dalam wilayah pelayanan kesehatan yang sama, dalam satu wilayah kecamatan Pare, Kabupaten Kediri. Krtiteria Eksklusi responden yang tidak hadir saat dilaksanakan kegiatan penelitian

\section{Pengetahuan Keputihan}

Pengetahuan keputihan adalah segala sesuatu yang diketahui remaja tentang keputihan. Instrumen menggunakan kuesioner. Dengan kriteria apabila menjawab benar maka nilai 1 sedangkan bila salah nilai 0 .

\section{Perilaku Hygienitas Genetalia}

Kegiatan atau tindakan remaja menjaga kebersihan genetalia.

Pengukuran Presentase Pengetahuan Remaja Putri Tentang Keputihan Dan Perilaku Hygienitas Genetalia

Pengetahuan remaja putri tentang keputihan dapat diketahui dari kuesioner yang telah diberikan pada responden kemudian diolah data sehingga diperoleh persentase yang menyatakan prosentasi kriteria pengetahuan yaitu kriteria baik, cukup dan kurang baik. Sedangkan perilaku higienitas genetalia dapat diketahui dari kuesioner yang diberikan pada responden yang dilakukan di SMPN 1 Pare kemudian diolah data sehingga muncul persentase yang menyatakan prosentasi kriteria perilaku higienitas Genetalia yaitu sangat baik, baik, cukup dan kurang baik.

\section{Analisis Statistik}

Analisis bivariat digunakan untuk mengetahui pengaruh antar variabel independen dan variabel dependen. Data dianalisis dengan menggunakan uji Rank Spearman. Untuk menentukan apakah terjadi pengaruh antara variabel independen dan variabel dependen, menggunakan uji Rank Spearman, dengan tingkat kesalahan yang digunakan yaitu 5\% atau 0,05. Apabila $\mathrm{p}$ value $\leq 0,05$ maka Ho ditolak, yang berarti ada hubungan yang signifikan antara variabel independen dan variabel dependen. Sedangkan untuk menguji adanya korelasi , kekuatan dan arah korelasi dilihat dari nilai $\left(r^{2}\right)^{7}$.

\section{Hasil Dan Pembahasan}

Hasil persentase Pengetahuan Remaja Putri Tentang Keputihan.

Tabel 1. Pengetahuan Remaja Putri tentang keputihan di SMP Negeri 1 Pare Kediri Tahun 2018. 


\begin{tabular}{l|l|l|l}
\hline No & Pengetahuan & $\begin{array}{l}\text { Jumlah } \\
(\mathrm{N})\end{array}$ & $\begin{array}{l}\text { Prosentase } \\
(\%)\end{array}$ \\
\hline 1 & Baik & 4 & 10,5 \\
\hline 2 & Cukup & 19 & 50 \\
\hline 3 & Kurang & 15 & 39,5 \\
\hline & Jumlah & 38 & 100 \\
\hline
\end{tabular}

Berdasarkan penelitian yang telah dilakukan pada 38 responden di SMP Negeri 1 Pare Kediri, diperoleh hasil bahwa pengetahuan tentang keputihan prosentase terbesar memiliki pengetahuan yang cukup yaitu 19 responden (50\%), pengetahuan baik sebanyak 4 responden $(10,5 \%)$ dan pengetahuan kurang sebanyak 15 responden $(39,5 \%)$.

Pengetahuan (knowledge) adalah hasil penginderaan terjadi melalui panca indera manusia, atau hasil tahu seseorang terhadap obyek melalui indera yang di milikinya (mata, hidung, telinga dan sebagainya). Sebagian besar pengetahuan seseorang diperoleh melalui indera pendengaran (telinga) dan indera penglihatan (mata) ${ }^{8}$. Hal ini dapat di lihat dari faktor yang melatar belakangi responden seperti pekerjaan, pendidikan, usia dan sumber informasi sedangkan faktor eksternal yaitu lingkungan dan sosial budaya. Faktor internal yang mempengaruhi pengetahuan, pendidikan dapat mempengaruhi seseorang termasuk juga perilaku seseorang. Pada umumnya semakin tinggi pendidikan seseorang, maka makin mudah orang tersebut untuk menerima informasi. Dapat dibuktikan dari hasil penelitian bahwa siswa kelas IX mempunyai pengetahuan baik tentang keputihan, sedangkan siswa kelas VII rata-rata responden memiliki pengetahuan kurang tentang keputihan. Menurut Hurlcok semakin cukup umur, tingkat kematangan dan kekuatan seseorang akan lebih matang dalam berfikir dan bekerja. Dari segi kepercayaan masyarakat seseorang yang lebih dewasa akan lebih di percayai dari orang yang belum cukup tinggi kedewasaannya. Hal ini sebagai akibat dari pengalaman dan kematangan jiwanya ${ }^{9}$.

Hal ini dapat dibuktikan dari hasil penelitian, bahwa responden yang rata-rata mempunyai pengetahuan cukup berusia 15 tahun, maka hal ini menunjukkan semakin dewasa usia seseorang ada kecenderungan untuk memiliki pengalaman hidup yang banyak lagi. Proses belajar dari pengalaman akan menjadi stimulasi bagi responden dalam menentukan pengetahuannya. Semakin dewasa seseorang (usia) maka makin tinggi tingkat pengetahuan seseorang tersebut karena mereka bisa belajar dari pengalaman sebelumnya. Selain faktor internal, ada juga faktor eksternal yang dapat mempengaruhi tingkat pengetahuan salah satunya adalah lingkungan. Lingkungan adalah seluruh kondisi yang ada di sekitar manusia dan pengasuhnya yang dapat mempengaruhi perkembangan dan perilaku orang atau kelompok. Menurut Ann. Mariner lingkungan adalah input kedalam diri seseorang sebagai sistem adaptif yang melibatkan baik faktor internal maupun eksternal ${ }^{8,10}$.

Menurut peneliti pengetahuan remaja putri tentang keputihan dengan perilaku hygienitas dipengaruhi oleh pendidikan, umur dan lingkungan. Semakin dewasa seseorang semakin baik pula pengetahuannya karena tingkat kematangan jiwanya semakin tinggi sehingga semakin mudah menerima informasi dan semakin tinggi pendidikan seseorang maka semakin mudah orang tersebut menerima informasi serta lingkungan dapat mempengaruhi perkembangan dan perilaku orang atau kelompok. Seharusnya tenaga kesehatan lebih banyak memberikan penyuluhan tentang keputihan dan cara menjaga hygienitas genetalia yang benar agar pengetahuan remaja putri baik.

Hasil persentase Perilaku Higienitas Genetalia:

Tabel 2. Perilaku hygienitas genetalia di SMP Negeri 1 Pare Kediri Tahun 2018

\begin{tabular}{l|l|l|l}
\hline No & $\begin{array}{l}\text { Perilaku } \\
\text { Hygienitas } \\
\text { Genetalia }\end{array}$ & $\begin{array}{l}\text { Jumlah } \\
(\mathrm{N})\end{array}$ & $\begin{array}{l}\text { Prosentase } \\
(\%)\end{array}$ \\
\hline 1 & Sangat Baik & 2 & 5,3 \\
\hline 2 & Baik & 29 & 76,3 \\
\hline 3 & Cukup & 7 & 18,4 \\
\hline 4 & Kurang & 0 & 0 \\
\hline & Jumlah & 38 & 100 \\
\hline
\end{tabular}

Berdasarkan penelitian yang telah dilakukan pada 38 responden di SMP Negeri 1 Pare Kediri, diperoleh hasil bahwa perilaku hygienitas genetalia mayoritas memiliki perilaku yang baik yaitu 29 responden 
(76,3\%), perilaku sangat baik sebanyak 2 responden $(5,3 \%)$ dan perilaku cukup sebanyak 7 responden $(18,4 \%)$.

Perilaku adalah suatu kegiatan atau aktifitas organisme (makhluk hidup) yang bersangkutan. Jadi yang dimaksud perilaku manusia pada hakikatnya adalah tindakan atau aktifitas dari manusia itu sendiri yang mempunyai bentangan sangat luas anatara lain, berjalan, berbicara, menangis, tertawa, bekerja, kuliah, menulis, membaca dan sebagainya. Semua kegiatan atau aktifitas manusia, baik dapat diamati langsung maupun tidak langsung yang diamati oleh pihak luar. Perilaku adalah keyakinan mengenai tersedianya atau tidaknya kesempatan dan sumber yang diperlukan ${ }^{8}$.

Menurut Loawrence Green bahwa perilaku itu sendiri dipengaruhi oleh beberapa faktor-faktor yaitu faktor predisposisi yang terwujud dalam pengetahuan, sikap, kepercayaan keyakinan, nilai-nilai dan motivasi. Faktor Enabling/pendukung yang terwujud dalam lingkungan fisik, tersedia atau tidak tersedianya fasilitas-fasilitas atau saranasarana kesehatan. Faktor Reenforcing/ pendorong yang terwujud dalam sikap dan perilaku petugas kesehatan atau petugas lainnya yang merupakan kelompok referensi dari perilaku masyarakat ${ }^{8}$.

Perilaku hygienitas genetalia yang baik dipengaruhi oleh faktor lain dan diri sendiri, faktor utama yang mempengaruhi perilaku adalah sikap, pengetahuan, konsep diri, kepercayaan, nilai dan informasi. Selain itu faktor demografi seperti status ekonomi, umur, jenis kelamin dan jumlah keluarga. Kemudian faktor pendukung yaitu sarana dan prasarana, dan yang terakhir faktor pendorong yakni keluarga dan lingkungan sekitar. Dalam perilaku hygienitas genetalia, maka yang paling mempengaruhi adalah lingkungan keluarga terutama ibu, karena seorang anak perempuan akan belajar dan menganut kebiasaan yang sudah ada sebelumnya dari keluarga terutama dari ibu. Maka walaupun mayoritas menunjukkan kurang pengetahuan, tetapi mayoritas perilaku baik sebab kebiasaan dan budaya dari ibu melekat erat pada perilaku anak, tetapi sebenarnya dia tidak mengerti bagaimana cara menjaga kebersihan genitalia yang baik dan benar. Menjaga kebersihan genetalia sangat penting, karena dengan menjaga kebersihan genetalia dapat menghindari bakteri-bakteri masuk ke dalam.
Jika kita dapat menjaga kebersihan genetalia maka kita dapat terhindar dari bakteri-bakteri yang jahat yang dapat menyebabkan terjadinya keputihan ${ }^{11,12}$. Pengetahuan seseorang yang rendah akan cenderung mengalami perilaku hygienitas genetalia yang kurang baik dibanding seseorang yang tingkat pengetahuannya tinggi. Semakin tinggi pengetahuan seseorang, maka perilaku hygienitas genetalianya semakin baik. Maka sebaliknya jika pengetahuannya rendah maka perilaku hygienitas genetalianya kurang baik.

Menurut peneliti peran keluarga, lingkungan tenaga kesehatan ataupun informasi dari buku-buku kesehatan, media elektronik, teman, guru, dan media massa seperti majalah, TV dan internet sangat diperlukan. terutama keluarga khususnya ibu sangat berperan penting dalam hal pemberian bimbingan untuk menciptakan perilaku hygienitas pada remaja putri karena ibu adalah role model bagi remaja dalam berperilaku menjaga hygienitas genetalia.

Hubungan Pengetahuan Remaja Putri Tentang Keputihan Dengan Perilaku Hygienitas Genetalia di SMP Negeri 1 Pare Kediri Tahun 2018 digambarkan dalam tabel berikut :

Table3. Tabulasi Silang Hubungan Pengetahuan Remaja Putri Tentang Keputihan Dengan Perilaku Hygienitas Genetalia di SMP Negeri 1 Pare Kediri Tahun 2018

\begin{tabular}{|c|c|c|c|c|c|c|c|c|c|c|}
\hline \multirow{3}{*}{$\begin{array}{l}\text { Pengeta } \\
\text { huan } \\
\text { Remaja } \\
\text { Putri } \\
\text { Tentang } \\
\text { Keputih } \\
\text { an }\end{array}$} & \multicolumn{10}{|c|}{ Perilaku Hygienitas Genetalia } \\
\hline & \multicolumn{2}{|c|}{$\begin{array}{l}\text { Sanga } \\
\mathrm{t} \text { baik }\end{array}$} & \multicolumn{2}{|c|}{ Baik } & \multicolumn{2}{|c|}{ Cukup } & \multicolumn{2}{|c|}{ Kurang } & \multicolumn{2}{|c|}{ Total } \\
\hline & $\mathrm{N}$ & $\%$ & $\mathrm{~N}$ & $\%$ & $\mathrm{~N}$ & $\%$ & $\mathrm{~N}$ & $\%$ & $\mathrm{~N}$ & $\%$ \\
\hline Baik & 2 & $\begin{array}{l}5 \\
0\end{array}$ & 2 & 50 & 0 & 0 & 0 & 0 & 4 & 100 \\
\hline Cukup & 0 & 0 & $\begin{array}{l}1 \\
9\end{array}$ & $\begin{array}{l}10 \\
0\end{array}$ & 0 & 0 & 0 & 0 & 19 & 100 \\
\hline Kurang & 0 & 0 & 8 & $\begin{array}{l}53 \\
, 3\end{array}$ & 7 & $\begin{array}{l}4 \\
6,\end{array}$ & 0 & 0 & 15 & 100 \\
\hline Jumlah & 2 & 5 & $\begin{array}{l}2 \\
9\end{array}$ & $\begin{array}{l}76 \\
6 \\
3\end{array}$ & 7 & $\begin{array}{l}1 \\
8, \\
4\end{array}$ & 0 & 0 & 38 & 100 \\
\hline
\end{tabular}


Berdasarkan tabel diatas menunjukkan bahwa didapatkan perilaku hygienitas genetalia yang sangat baik dari pengetahuan remaja putri tentang keputihan yang baik sebanyak 2 responden $(50 \%)$ lebih besar dibandingkan yang berpengetahuan cukup 0 responden $(0 \%)$ dan kurang 0 responden $(0 \%)$. Perilaku hygienitas genetalia yang baik dari pengetahuan remaja putri tentang keputihan yang cukup sebanyak 19 responden $(100 \%)$ lebih besar dari yang berpengetahuan baik sebanyak 2 responden $(50 \%)$ dan kurang sebanyak 8 responden $(53,3 \%)$. Perilaku hygienitas genetalia yang cukup dari pengetahuan remaja putri tentang keputihan yang kurang sebanyak 7 responden $(46,7 \%)$ dibanding yang berpengetahuan cukup 0 responden $(0 \%)$ dan 0 responden $(0 \%)$ baik. Hasil uji statistik penelitian Hubungan Pengetahuan Remaja Putri Tentang Keputihan Dengan Perilaku Hygienitas Genetalia di SMP Negeri 1 Pare Kediri Tahun 2019 adalah sebagai berikut : Hasil perhitungan korelasi Rank Sperman dapat dilihat pada lampiran untuk lebih jelasnya dapat dilihat dibawah ini

Tabel 4. Hasil perhitungan korelasi Rank Spearman

\begin{tabular}{l|l|l|l}
\hline Indikator & Sig. & $\begin{array}{l}\text { Korela } \\
\text { si (r) }\end{array}$ & $\begin{array}{l}\text { Keteranga } \\
\mathrm{n}\end{array}$ \\
\hline $\begin{array}{l}\text { Hubungan } \\
\text { pengetahua }\end{array}$ & 0,00 & 0,780 & Ho ditolak \\
n remaja & & & \\
$\begin{array}{l}\text { Putri } \\
\text { tentang } \\
\text { keputihan } \\
\text { dengan } \\
\text { perilaku } \\
\text { hygienitas } \\
\text { genetalia }\end{array}$ & & & \\
\hline
\end{tabular}

Dari hasil uji statistik Spearman Rank didapatkan adanya hubungan pengetahuan remaja putri tentang keputihan dengan perilaku hygienitas genetalia dengan nilai signifikan adalah $0,000 \quad(\mathrm{p}=0,000)$, tingkat kesalahan yang dipilih adalah $5 \%(\alpha=0,05)$, $\mathrm{p}<\alpha$ yang berarti Ho ditolak dan H1 diterima artinya ada Hubungan Pengetahuan Remaja Putri Tentang Keputihan Dengan Perilaku Hygienitas Genetalia di SMP Negeri 1 Pare Kediri Tahun 2018. Hasil penelitian menggunakan uji statistik Spearman Rank diperoleh hasil koefisien kolerasi spearman $(\mathrm{r})=0,780$ dan tanda positif (korelasi kuat) dengan demikian tingkat hubungan termasuk positif artinya semakin baik pengetahuan maka semakin baik perilaku hygienitas genetalianya dan tingkat hubungan antara keduanya kuat.

Pengetahuan (knowledge) adalah hasil penginderaan terjadi melalui panca indera manusia, atau hasil tahu seseorang terhadap obyek melalui indera yang di milikinya (mata, hidung, telinga dan sebagainya). Sebagian besar pengetahuan seseorang diperoleh melalui indera pendengaran (telinga) dan indera penglihatan (mata). Hal ini dapat di lihat dari faktor yang melatar belakangi responden seperti pekerjaan, pendidikan, usia dan sumber informasi sedangkan faktor eksternal yaitu lingkungan dan sosial budaya ${ }^{8}$. Pengetahuan seseorang dapat diketahui dan diinterprestasikan dengan skala yang bersifat kualitatif, yaitu baik, cukup, kurang. Berdasarkan hasil penelitian pengetahuan remaja putri tentang keputihan mayoritas memiliki pengetahuan yang cukup yaitu 19 responden $(50 \%)$, pengetahuan baik sebanyak 4 responden (10,5\%) dan pengetahuan kurang sebanyak 15 responden $(39,5 \%)$.

Perilaku adalah suatu kegiatan atau aktifitas organisme (makhluk hidup) yang bersangkutan. Jadi yang dimaksud perilaku manusia pada hakikatnya adalah tindakan atau aktifitas dari manusia itu sendiri yang mempunyai bentangan sangat luas anatara lain, berjalan, berbicara, menangis, tertawa, bekerja, kuliah, menulis, membaca dan sebagainya. Menurut Loawrence Green bahwa perilaku itu sendiri dipengaruhi oleh beberapa faktor-faktor yaitu faktor predisposisi yang terwujud dalam pengetahuan, sikap, kepercayaan keyakinan, nilai-nilai dan motivasi. Faktor Enabling / pendukung yang terwujud dalam lingkungan fisik, tersedia atau tidak tersedianya fasilitasfasilitas atau sarana-sarana kesehatan. Faktor Reenforcing/ pendorong yang terwujud dalam sikap dan perilaku petugas kesehatan atau petugas lainnya yang merupakan kelompok referensi dari perilaku masyarakat ${ }^{8}$.

Berdasarkan penelitian yang diperoleh hasil bahwa perilaku hygienitas genetalia sebagian besar memiliki perilaku yang baik yaitu 29 responden $(76,3 \%)$, perilaku sangat baik sebanyak 2 responden $(5,3 \%)$ dan perilaku cukup sebanyak 7 responden 
$(18,4 \%)$. Sedangkan dari hasil pengujian hubungan antara dua variabel pengetahuan tentang keputihan memberikan pengaruh terhadap perilaku hygienitas genetalia. Dari data yang ada menunjukan perilaku hygienitas genetalia yang sangat baik dari pengetahuan remaja putri tentang keputihan yang baik sebanyak 2 responden $(50 \%)$ lebih besar dibandingkan yang berpengetahuan cukup 0 responden (0\%) dan kurang 0 responden $(0 \%)$. Perilaku hygienitas genetalia yang baik dari pengetahuan remaja putri tentang keputihan yang cukup sebanyak 19 responden $(100 \%)$ lebih besar dari yang berpengetahuan baik sebanyak 2 responden (50\%) dan kurang sebanyak 8 responden $(53,3 \%)$. Perilaku hygienitas genetalia yang cukup dari pengetahuan remaja putri tentang keputihan yang kurang sebanyak 7 responden $(46,7 \%)$ dibanding yang berpengetahuan cukup 0 responden $(0 \%)$ dan 0 responden $(0 \%)$ baik.

Hasil penelitian tersebut sesuai dengan teori Hidayat, A yaitu pengetahuan seseorang yang rendah cenderung memiliki perilaku yang tidak baik. Semakin tinggi pengetahuan seseorang, maka makin baik perilakunya ${ }^{8}$. Hal ini juga sesuai dengan penelitian yang dikemukanan Menthari H (2015) yang menyatakan ada hubungan Tingkat Pengetahuan tentang keputihan dengan Perilaku Pencegahan Keputihan pada remaja putri SMA di Manado. Juga Sesuai dengan penelitian Nanlessy, D. M., Hutagaol, E \& Wongkar, D (2013) ada hubungan antara pengetahuan dan perilaku remaja puteri dalam menjaga kebersihan alat genitalia di SMA N 2 Pineleng. ${ }^{13,14}$

Menurut peneliti perbedaan pengetahuan pada setiap remaja berbeda karena dipengaruhi oleh beberapa faktor antara lain, pendidikan, umur, dan lingkungan. Sedangkan perbedaan perilaku dipengaruhi karena tingkat pengetahuan yang berbeda. Pengetahuannya cukup karena informasi yang cukup baik dari orang tua, saudara ataupun informasi dari buku-buku kesehatan, media elektronik, teman, guru dan media massa seperti majalah, TV dan inernet. Orangtua sangat berperan penting dalam hal pemberian bimbingan karena lingkungan keluarga merupakan lingkungan yang sangat dekat dengan remaja putri. Menanggapi perilaku hygienitas genetalianya menunjukkan semakin baik pengetahuan remaja putri tentang keputihan maka semakin baik perilaku hygienitas genetalianya. Hal ini dikarenakan mereka sudah mendapatkan informasi atau pengetahuan yang cukup dari keluarga, lingkungan sekitar, sekolah dan buku-buku kesehatan sehingga dalam menerima hal-hal yang baru mereka dapat mengantisipasi dengan baik dan sebaliknya semakin rendah informasi yang didapat sehingga pengetahuan yang dimiliki juga kurang. Untuk memperoleh pengetahuan baik maka diperlukan informasi yang cukup banyak. Oleh karena itu, perlu adanya bimbingan dari orang tua khususnya ibu, tenaga kesehatan, informasi dari lingkungan sekitar, sekolah, serta buku-buku kesehatan tentang keputihan. Sehingga remaja putri semakin banyak tahu tentang keputihan dan perilaku hygienitas genetalia yang baik.

\section{Kesimpulan Dan Saran \\ Kesimpulan.}

Terdapat Hubungan Pengetahuan Remaja Putri Tentang Keputihan dengan Perilaku Higienitas Genetalia. Hasil penelitian didapatkan kekuatan tingkat hubungan antara keduanya adalah kuat. artinya semakin baik pengetahuan maka semakin baik perilaku.

\section{Saran}

Sebaiknya ada penelitian lanjutan mengenai factor lain yang mempengaruhi perilaku HBigienitas Genetalia.

Saran dari peneliti saran bagi tempat penelitian diharapkan hasil penelitian ini memberikan masukan pada instansi dalam pengembangan informasi tentang kesehatan reproduksi, khususnya tentang keputihan. Pihak sekolah bisa bekerja sama dengan tenaga kesehatan yang lain dalam melakukan pendekatan pada siswinya dengan memberikan penyuluhan tentang keputihan, sehingga dapat memiliki perilaku hygienitas genetalia yang baik. Sedangkan bagi responden adalah remaja putri sebaiknya meningkatkan pengetahuan tentang Keputihan sehingga dengan pengetahuan yang baik maka perilaku hygienitas genetalia baik. Upaya ini dapat ditempuh dengan banyak membaca, melihat televisi atau mencari informasi kepada tenaga kesehatan.

\section{Ucapan Terima Kasih}

Disampaikan terima kasih kepada STIKes Pamenang dan SMPN 1 Pare Kabupaten Kediri yang telah memberikan 
kami izin untuk melakukan penelitian serta memfasilitasi kebutuhan dalam penelitian ini

\section{Daftar Pustaka}

Marmi. Kesehatan Reproduksi. Yogyakarta: Pustaka Pelajar; 2013.

Kusmiran E. Kesehatan Reproduksi Remaja Dan Wanita. Jakarta: Salemba Medika; 2012.

Ayuningtyas, D. 2011. Hubungan Antara Pengetahuan Dan Perilaku Menjaga Kebersihan Genetalia Eksterna Dengan Kejadian Keputihan Pada Siswa SMA Negri 4 Semarang. JNKI, Vol 3, No.1, Tahun 2015; $39-42$

Romlah, S. N. 2017. Tingkat pengetahuan Dan Sikap Remaja Puteri Tentang Keputihan Pada Siswi Kelas XI SMA 1 Alghozali Bogor. Jurnal Sekolah Tinggi Ilmu Kesehatan Widya Dharma Husada, Vol 3, No.1, Juni 2017

Armeliza, V. 2012. Gambaran Konsep Diri Remaja di Lembaga Pemasyarakatan. Pekan Baru, e-journal Universitas Samratulangi, Vol. 4, No.1, 2015

Poltekkes Depkes Jakarta I. Kesehatan Remaja Problem dan Solusinya. Jakarta: Salemba Medika; 2010

Sugiyono. Statistik Untuk Penelitian. Bandung : Alfabeta; 2009

Notoatmodjo. Pendidikan dan Perilaku Kesehatan. Jakarta:Rineka Cipta; 2010
Wawan, Dewi. A. Teori dan Pengukuran, Sikap dan Perilaku Manusia. Yogyakarta; Nuha Medika; 2011

Pamaruntuan. 2014. Hubungan Antara Pengetahuan Tentang Keputihan dan Hygiene Perorangan Dengan Kejadian Keputihan Pada Siswi Sekolah Menengah Atas Negeri 4 Manado. Manado: Fakultas Kesehatan Masyarakat Universitas Sam Ratulangi Manado.

Maidartati. 2016. Hubungan Pengetahuan Dan Perilaku Vulva Hygiene Pada Saat Menstruasi Remaja Putri. Universitas BSI Bandung, Jurnal Ilmu Keperawatan, Vol. IV, No. 1, April 2016

Lufiati. 2015. Faktor - faktor Yang Berhubungan Dengan Perilaku Personal hygiene Organ Genitalia Pada Pelajar Putri Di Smk N 7 Surakarta. Surakarta: FIK Universikas Muhammadiyah Surakarta.

Mokodongan, M. 2015. Hubungan Pengetahuan Tentang Keputihan Dengan Perilaku Pencegahan Keputihan Pada Remaja Putri SMA di Manado. jurnal e-clinic (eCl) Volume 3, Nomor 1, Januari - April 2015

Nanlessy, D. Hutagaol, E. Wongkar, J. 2013. Hubungan antara pengetahuan dan perilaku remaja puteri dalam menjaga kebersihan alat genitalia dengan kejadian di SMA N 2 Pineleng, 1-15. e jurnal Keperawatan (e-Kp) Vol. 1, No. 1, Agustus 2013 